(cC) BY-NC-ND

\title{
Regional Civil Security Cooperation in South Eastern Europe: The Case of Disaster Preparedness and Prevention Initiative ${ }^{1}$
}

\author{
Želimir Kešetović \\ University of Belgrade, Faculty of Security Studies, \\ Gospodara Vučića 50, 11000 Belgrade, Serbia
}

\section{Višnja Samardžija}

Institute for Development and International Relations - IRMO,

Ljudevita Farkaša Vukotinovića 2, 1000 Zagreb, Croatia

doi:10.13165/VPA-14-13-2-02

Abstract. The paper aims to explore the quality aspect of Disaster Preparedness and Prevention Initiative as a regional organization in South Eastern Europe (DPPI SEE) striving to enhance the overall crisis management capacity in this crisis prone region.

The research is based on secondary sources analysis and in depth interviews with stakeholders.

The Disaster Preparedness and Prevention Initiative for South Eastern Europe is the only regionally owned initiative in South Eastern Europe which includes 11 partner states (Albania, Bosnia and Herzegovina, Bulgaria, Croatia, Macedonia, Montenegro, Moldova, Romania, Slovenia, Serbia and Turkey) and two states with observers status (Hungary and Greece). The DPPI SEE was launched in November 2000 by the Stability Pact for South Eastern Europe in order to facilitate the cooperation and coordination of the SEE countries in preventing, preparing and strengthening capabilities to respond to natural and man-made, i.e., technological, disasters. After transforming

1 The research leading to these results has received funding from the European Union's Seventh Framework Programme FP7/2007-2013 under grant agreement n² 284678 . 
the Stability Pact for South Eastern European 2008, the DPPI SEE came under the umbrella of Regional Cooperation Council. In the same year, a Memorandum of Understanding, as the only legal basis regulating its objectives, structure and decisionmaking process, was signed by partner countries. DPPI SEE activities are on capacity building of partner countries aimed to enhance disaster preparedness and prevention through disaster management education and training courses, including organization of workshops, seminars, conferences, etc. Significant achievements have been made throughout the implementation of several regionally owned projects. Nevertheless, besides the important results that have been achieved in the work of the DPPI SEE to date, certain weaknesses and shortcomings have been demonstrated. The DPPI is now at some sort of milestone anticipating the new Memorandum of Understanding.

Keywords: crisis, disaster, crisis management, regional cooperation, South Eastern Europe.

\section{Introduction}

South Eastern Europe is prone to disasters that transcend national borders and overwhelm the coping capacities of a single country ${ }^{2}$. The level of preparedness and prevention capacity varies considerably from country to country. The Disaster Preparedness and Prevention Initiative for South Eastern Europe is the only regionally owned initiative dealing with disasters in South Eastern Europe, which includes 11 partner states (Albania, Bosnia and Herzegovina, Bulgaria, Croatia, Macedonia, Montenegro, Moldova, Romania, Slovenia, Serbia and Turkey) and two states with observers status (Hungary and Greece). The DPPI SEE was launched in November 2000 by the Stability Pact for South Eastern Europe in order to facilitate the cooperation and coordination of the SEE countries in preventing, preparing and strengthening capabilities to respond to natural and man-made, i.e. technological, disasters. After transforming the Stability Pact for South Eastern European 2008, the DPPI SEE came under the umbrella of Regional Cooperation Council. In the same year, a Memorandum of Understanding, as the only legal basis regulating its objectives, structure and decision-making process, was signed by partner countries. DPPI SEE activities are on capacity building of partner countries aimed to enhance disaster preparedness and prevention through disaster management education and training courses, including organization of workshops, seminars, conferences, etc. Significant achievements have been made throughout the implementation of several regionally owned projects. The DPPI is currently undergoing a process of institutional amendments and adjustments in order to improve its efficiency and better meet the needs of Party states.

2 Main risks refer to floods, fires, earthquakes and hazard materials. Also, between some of SEE countries, there are territorial disputes and legacy of recent wars that followed the dissolution of SFR Yugoslavia. See more in [13]. 


\section{Theoretical background}

In countries in transition, crisis management is a relatively new concept, both in the theoretical sense as a scientific-educational discipline and research field, and as a practical activity in private corporations, state administration, state-owned companies and organizations in the non-profit sector [9]. In a global perspective, among a plethora of emerging literature and different concepts, the authors of the present paper consider the cognitive-institutional approach to the study of crises and crisis management as the most promising [12]. When it comes to international cooperation in crisis management, the focus of researches has been mainly on the UN [11], the EU [3], [4], and NATO [15], while regional organizations have been studied less. This specially refers to the DPPI SEE, which was incidentally mentioned in the context of regional cooperation and response to a certain kind of emergency situations or within international relations and politics studies [5], [14], [10].

\section{Research methodology}

The regional organisation mapping procedure for the DPPI followed the joined methodology of the FP7 project ANVIL - Analyses of civil security systems in Europe [ANVIL Mapping Protocol] based on collection and analyses of data from primary (interviews based to the extent possible among relevant institutions and experts at national level) and secondary sources aiming to analyse the role of regional organisation in regional cooperation, building civil security architecture, experiences and practices. In approaching the quality assessment of the DPPI SEE, three dimensions have been taken into consideration: effectiveness, efficiency and legitimacy. The governments and stakeholders were those actors the authors of the present paper primarily looked at, through a dual track approach. On the one hand, the authors of the paper conducted interviews with DPPI SEE Secretariat staff and government officials from emergency management agencies from Serbia, Croatia and Bosnia and Herzegovina. At the same time, the authors of the paper conducted an analysis of available sources, including studies and reports, official documents, articles and news related in order to draw indications on government and stakeholders' evaluation of the DPPI SEE in terms of effectiveness and legitimacy.

\section{Results and findings}

When analysing the overall DPPI SEE quality, one faces with a number of problems, such as a lack of analytical documents, academic researches, annual reports, notes from the meetings, or other documents. DPPI Website provides only basic, very general and not very accurate information. Problems exist also in an attempt to obtain the data from the stakeholders. So far, except the study done 
by Balkan Institute for Risk Assessment and Emergency Management [2], there have been no comprehensive assessment of DPPI SEE achievements, so the quality measure is based on this study and interviews with stakeholders/key informants. This is partly resulting from the fact that the DPPI SEE is a relatively young regional organisation, but it clearly shows that there is a need for a more comprehensive analytical research focus on regional aspects of disaster preparedness and prevention management.

\section{Capacity building dimension}

The main activities of the DPPI SEE are related with capacity building of member countries through organizing training courses, exercises, conferences and implementing different joint projects aimed to improve preparedness and prevention within disaster management.

Significant achievements refer to project facilitation, and related activities are aimed to support SEE countries to prepare feasible project proposals and to strengthen regional cooperation by providing a coordinative platform and international methodology in use [through Project Management Cycle training courses]. It has resulted in several regionally owned projects, such as Seismological zoning, led by Moldova, for Bulgaria, Moldova and Romania, and Hydro meteorological Network for SEE, led by Croatia, coordinated with compatible projects within the Sava Agreement Initiative with support of NATO PfP, Project Earthquake Monitoring in Support of Disaster Preparedness in SEE, coordinated by the European Mediterranean Seismological, etc. Increased cooperation with IFRC, UNDP, NATO, Swedish Search and Rescue Services Agency, RACVIAC, Civil Military Emergency Planning Council for SEE (CMEPC), East-West Institute and NGO HELP has been achieved as well as a good network with others, such as COE EUR-OPA Major Hazard Agreement, COE Bank, CEI and a closer cooperation with ECDG Environment - CP was initiated [18].

Support to the region's capacity takes several forms through DPPI SEE activities. The following projects and training courses should be mentioned [18].

DPPI SEE Capacity Development for Disaster Risk Reduction in South East Europe is a very important project. This project is aimed to create sustainable capacities in the DRR and to develop a multiplication effect by initiating a pool of trainers from the region that was able to pursue the objectives and results of the project in the long run. The project was realised in the period 2009-2012. In the first phase, training needs analysis was conducted and training course was designed, two pilot courses were held, the course was adjusted and Train of Trainers course was held, followed by two DDR courses. In the second phase, two Train of Trainers and three DDR courses were held. Building Capacity in the DRR in the region gained more support with the establishment of the DPPI SEE [6]. 
Disaster Management Training Program (DMTP) consists of workshops, seminars, training courses and conferences. The events are held in many of the South East Europe countries. Hosting an event is voluntary. Financing of the DMTP activities is normally shared between the host country and the DPPI SEE budget. The project goal is to enhance disaster preparedness and prevention through disaster management education and training as well as to train and practice disaster response, with the aim of strengthening cooperation among all participants in protection and rescue activities, harmonizing the activities of the participants in order to eliminate possible failures and promoting the understanding of national and international principles related to disaster management.

The overall objective of the Project called "Joint Fire Fighting Units between Bosnia and Herzegovina, Croatia and Montenegro" is to improve preparedness and prevention and response to open fires in the coastal area, regardless of national borders, with jointly trained rapid fire-fighting response units between Bosnia and Herzegovina, Croatia and Montenegro. Within the framework of the project, 8 Emergency Response Teams have been formed and 72 fire fighters have been trained and equipped. The JFFU project was successfully finalized with a final Joint FireFighting Exercise held in Budva, 27 May, 2004. The project was implemented by the Governmental organizations responsible for civil protection, disaster management and rescue in participating countries.

"Trilateral Border Crossing Protocols/Procedures" have been developed between Bosnia and Herzegovina, Croatia and Montenegro. The main objective of the project is to initiate preparations for the provision of a legal and operational framework to be used for a rapid border crossing in joint interventions and providing mutual assistance in emergencies, including forest fires.

TheTThththtA The trilateral working group, composed of experts in the field of Protection and Rescue, Customs and Border Police, prepared and agreed upon the final version of the Protocol and the Protocol's attachments.

The parties involved in the project initiated national procedures for obtaining necessary approvals for signing protocols. All three interested parties have discussed Facilitation on the Border Crossing Protocols/Procedures and they expressed readiness to utilize additional efforts to accelerate the acceptance and signing of the Protocols.

The main technical objectives of the project "Seismic Maps Project" are to make appropriate integrated seismological and seismo-tectonical databases and to prepare seismic hazard maps for the region, harmonized with the European standards; to implement technical and scientific training programs for young scientific staff at the national seismological centers in the region. Planners, engineers and civil protection agencies are engaged to ensure the improvement in disaster management and seismic hazard assessment process.

The objective of the project called The DPPI SEE and UNDP - Building Capacity in Disaster Risk Reduction through Regional Cooperation and 
Collaboration in South East Europe (SEE) is to reduce the risk of disasters associated with natural hazards in the Western Balkans and Turkey, in line with the Hyogo Framework for Action, by building the capacity of national and local authorities and promoting a coordinated approach in disaster risk reduction. The specific objective of the project is to increase regional disaster risk reduction cooperation in the Western Balkans and Turkey and promote the harmonization of their disaster risk reduction methodologies, plans and strategies in order to pave the way for the eventual preparation of a harmonized and mutually accepted regional disaster risk reduction strategy in South East Europe.

The aim of the programme called The DPPI SEE and UNISDR/CADRI (United Nations Capacity for Disaster Reduction Initiative) - Human Capital Development on DRR Training is to support the development of disaster risk reduction capacity at all levels within the South East European region governments and organizations in order to improve their ability to better understand and manage the variety of disasters the region faces today. The program is also aiming to create a pool of professional trainers of trainees which will function as the main resources for DRR training in the region. In addition, they will be included in a pool of DRR expert database to be developed by the ISDR for the DPPI SEE.

Participating countries with their operational capabilities in "The Project for Support of Establishing the Joint Emergency Response Units in Case of Floods in SEE" will institute regional cooperation and coordination of disaster preparedness and prevention for regular information exchange with regard to water management and floods. Participating countries, with support from the Donors and RCC, will establish, equip and train Emergency Response Units in case of floods in the region of SEE. The Joint Emergency Response Units should be enabled to cross state borders in a fast manner in order to able to assist the flood affected areas in the neighbouring countries ${ }^{3}$.

The International Conference on Disaster Preparedness in South East Europe has been organized jointly with the George C. Marshall European Centre for Security Studies and in cooperation with the National Protection and Rescue Directorate of Croatia with more than 80 participants from 11 SEE countries and 18 international organizations and initiatives. The Conference goals were to provide national perspectives on the current status of disaster preparedness in the region, to identify disaster preparedness and emergency response roles and responsibilities, to discuss the need for civil-military cooperation and to ascertain further crisis response and consequence management challenges.

There is assessment after each training activity that serves as the basis for fine adjustment of future training courses. However, there are no analysis if and how those training courses have enhanced the institutional capacities of the member states and enhanced their preparedness and prevention measures.

The 5th Project Draft was written in March 2012. 


\section{Financing}

While being under the Stability Pact for SEE, the annual budget of the DPPI SEE was around $€ 600,000^{4}$ and after transferring to the regional ownership and financing by the member states contributions, the budget was reduced by almost three times, as each member state's contribution equals to the amount of $€ 25,000$ [in total, $€ 275,000]^{5}$. As the minimal country contribution of $€ 25,000$ is always the same, the fixed part of the budget for each year is the same also. The budget is managed by the DPPI SEE Secretariat and directed to activities planned and agreed between the member countries and donors at regional meetings. The financial dimension of transition of the DPPI SEE has been successfully resolved with transferring the treasuring role for the DPPI SEE from International Organisation for Migration to Regional Cooperation Council, including the signature of the employment contracts with the DPPI SEE Secretariat staff and the opening of a sub-account for the DPPI for its daily operations within the limitations of the present "Financial Protocol" signed between the RCC and the DPPI SEE Chair-in-Office (CiO) on December 2008. As the Financial Protocol signed between the RCC and the DPPI SEE does not represent a financial administrative document, the DPPI SEE urgently requires adoption of, inter alia, internal regulations for managing its financial matters, such as procurement of goods and services, in addition to defining Rules of Procedure.

According to the results of interviews conducted by Balkan Institute, more donors funding for projects should be secured. More activities should be financed through projects' diversity.

Unspent funds at the end of every budget year shall be treated in accordance with the agreement between the DPPI SEE and its contributors. Break-down of the budget is not possible because of the relatively narrow frame of the work of the DPPI SEE that is based on covering costs by the Secretariat and the implementation of a relatively small and limited number of training and education projects. The problem may be a fact that some member states are not paid regularly DPPI predicted contributions.

Among the member states to some extent there is asset sharing and/or asset procurement through the DPPI SEE. Some firefighting equipment has been purchased through JFFU project for the firefighters from Croatia, Montenegro and Bosnia and Herzegovina.

\section{Qualitative aspects - perception of the DPPI SEE among participating countries}

The main motivation of the member states to cooperate through the DPPI SEE is networking, information exchange and rapid communication. Expectations of

4 Norway, Switzerland and the United States of America have funded the DPPI SEE.

5 Each member state annually contributes to the proper functioning of the DPPI SEE by paying a membership fee of 25.000 euros, which demonstrates the equality among the member states. 
some member countries regarding the professional performance of the DPPI SEE have been much higher. This gap may be explained by a small number of employees in the DPPI Secretariat, lack of desire for full cooperation of some member states and the reality of the great diversity in their status in the process of the European integration. Interviewed Heads of Sectors are not satisfied with the role of the DPPI SEE in emergencies, since one of its roles is internal coordination with the DPPI SEE member countries and coordination with international donors. It is, thus, highly important to acknowledge the necessity to address the issue of the DPPI SEE capacity enhancement through establishment and maintenance of its role as a key coordinator among sectors, ministries and organizations in the field of disaster preparedness, prevention and response [18].

The member states do not use the DPPI SEE when crisis occurs as there is no mandate for this. They by-pass the formal mechanisms and contact each other bilaterally in accordance with bilateral agreements regulating protection and rescue as well as rendering assistance in case of disasters. Sometimes, the EU Member countries by-pass the DPPI SEE in favour of the EU Community Mechanism for Civil Protection.

Heads of emergency management authorities of some countries believe that all member countries should be more dedicated to achieving DPPI SEE goals. Also, among the member states, there are different opinions on certain issues, such as the potential Kosovo and Metohija membership on the DPPI SEE [18], [19], [20], [21].

It is necessary to develop interest in each sector of emergency management functioning, to obtain more knowledge about the existing problems and extend competencies to other ministries that may be part of issues of the disaster preparedness, prevention and response concept. The DPPI SEE Chair-in-Office should also endeavour to establish contact with potential private financiers and sponsors in the region, as well as with the World Bank aiming to ensure financial support to the DPPI SEE Secretariat activities. Based on the results of the survey and answers provided by the DPPI SEE member countries, it has been concluded that the current capacity of the DPPI SEE to address the issues of disaster management in the region requires further strengthening to better meet the needs of the SEE region. According to available documentation, it has been confirmed that so far, the DPPI SEE Secretariat has adopted one important document only - the Memorandum of Understanding on DPPI SEE Institutional Framework. Having in mind that the DPPI SEE member countries have made commitment to ensure legal existence and functioning of the DPPI SEE Secretariat, it is necessary to acknowledge these commitments and agree on any necessary steps to be taken in order to avoid the possibility of illegal and impractical functioning of the DPPI SEE, as well as redefining DPPI SEE legal status in such a way as to ensure proper future functioning of the Initiative. Further to the aforementioned, the DPPI SEE should be capable of operating with very basic essential administrative, legal, finance, logistics, information communication, media relations, project implementation, fund raising, etc. Also, capacity building is possible with usage of "Staff Secondment" as well as 
"internship" mechanisms. Additionally, in the case of the possibility of employing added staff to the Secretariat, that kind of decisions should be put into the agenda of future Regional Meetings, where decisions would be made by the Heads of Disaster Management Sectors of the Member States. Official communication within the DPPI SEE should be operational, clear and on daily basis, so that the operational side may be improved. Additional operational and secretariat staff should be employed, but the Head of the Secretary and other employees should reach their full capacities [2].

There are views among participating countries that the role and position of the Host Country should be subject to discussion between the Heads of Sectors, but parts of MoU defining the host country's role should be redefined. A more active involvement of the Advisory Board in the DPPI SEE decision-making process and CiO's more often seek the advice from experts in the region, thus establishing stronger cooperation with other relevant international organizations and potential donors and, in addition, a possibility for the Advisory Board to become an integral part of the Secretariat. A new set up of roles within the DPPI SEE should include the establishment of the Steering Body competent for discussing issues of utmost importance for the DPPI SEE in general. This body would be composed of deputies and executives of the DPPI SEE EM Sectors with decisions binding by a two-thirds majority vote [2].

As regards the role of the DPPI SEE Partners, it is advised that their individual activities within the Initiative should be closely monitored by the DPPI SEE member countries, in addition to defining their roles within the initiative [2] $]^{6}$.

\section{Conclusions}

1. In the region of SEE, where due to the geography and political borders disasters have a regional dimension, the DPPI SEE has developed into an effective consultative and coordinative mechanism enhancing disaster preparedness and prevention in case of natural and man-made disasters in South Eastern Europe [1]. The DPPI SEE has to a certain extent fulfilled its purpose and mandate and met some of the objectives for which it was established. A certain influence on it had the transfer from European to regional ownership, related decline of funding and different status of the member states in EU accession process, causing their different position, perspectives and interests.

2. The DPPI SEE has proved to be a relatively applicable tool for regional cooperation, especially in regards to prevention and preparedness in the field of disaster management. The DPPI SEE is the only regionally owned initiative in South East Europe, and as such, it is welcomed and appreciated 
by the international community and international organizations (EC, UN), which provides a basis for further strengthening of the regional cooperation through implementation of different projects, which aim to build capacities of the member states in disaster management. The role of the DPPI SEE in the emergency management should be reflected in internal coordination among the DPPI SEE member countries and with international donors alike. The DPPI SEE is encouraging the existing cooperation with NATO, $\mathrm{UN}$ and other internationally recognized organizations as key partners for the successful implementation of its own activities in the region. The DPPI SEE today is considered as a confident and reliable regional partner addressing trans-boundary issues and problems. The DPPI SEE member countries also recognize this fact and seek to further promote the values of the Initiative. Through different projects and activities, the DPPI SEE is promoted not only nationally, but also regionally as a desirable form of multilateral cooperation.

3. To conclude, one of the most important achievements of the DPPI SEE is Capacity Development for Disaster Risk Reduction in South East Europe. Support to the region's capacity takes several forms through DPPI SEE activities: training (Disaster Management Training Program), Projects (Joint Fire Fighting Units between Bosnia and Herzegovina, Croatia and Montenegro, Trilateral Border Crossing Protocols/Procedures, Seismic Maps Project, The DPPI SEE and UNDP - Building Capacity in Disaster Risk Reduction through Regional Cooperation and Collaboration in South East Europe, The DPPI SEE and UNISDR/CADRI - Human Capital Development on DRR Training, The Project for Support of Establishing the Joint Emergency Response Units in Case of Floods in SEE), organizing conferences, etc. The region's track record in the DRR has never looked better.

4. Significant achievements also refer to project facilitation, and related activities are aimed to support SEE countries to prepare feasible project proposals and to strengthen regional cooperation by providing a coordinative platform and international methodology in use (through Project Management Cycle training courses). It has resulted in several regionally owned project proposals, such as Seismological zoning, led by Moldova, for Bulgaria, Moldova and Romania, and Hydro meteorological Network for SEE, led by Croatia, coordinated with compatible projects within the Sava Agreement Initiative with support of NATO PfP, Project Earthquake Monitoring in Support of Disaster Preparedness in SEE, coordinated by the European Mediterranean Seismological, etc.

5. Cooperation with IFRC, UNDP, NATO, Swedish Search and Rescue Services Agency, RACVIAC, Civil Military Emergency Planning Council for SEE (CMEPC), East-West Institute and NGO HELP has been achieved as well as a good network with others, such as COE EUR-OPA Major Hazard Agreement, COE Bank, CEI and a closer cooperation with ECDG 
Environment - CP was initiated, and it is expected that it will increase in the future.

\section{Suggestions}

The DPPI SEE should focus on joint projects and involve all the relevant international organizations. It should endeavour to expand cooperation with international organizations, such as UNISDR, UN-OCHA and NATO- EDARCC. The DPPI SEE should act in a more coordinated and collaborative manner in order to minimize disaster risks. Developing regional, bilateral and multi-lateral relationships is important for securing human beings to live in a more disaster resistant environment. Since the DPPI SEE has been recognized by a number of relevant international organizations (UN, EC, etc.), it is highly recommended that the mutual cooperation is further strengthened and supported through realization of regional and bilateral projects. The effective implementation of the DPPI SEE mission in future will depend on full engagement of all stakeholders, including civil society, local and provincial authorities and governments and international organizations. A necessary precondition is redefining the legal basis, e.g., the Memorandum of Understanding as the only document that precise the mandate, structure, decision making and functioning of the DPPI SEE.

\section{Bibliography}

Books and articles:

1. Agic, S. Subregionalni concept redukcije rizika od prirodnih i drugih nesreća na prostoru Zapadnog Balkana [Subregional Concept of Risk Reduction of Natural and Other Disasters in the Western Balkan]. PhD thesis. Belgrade: Megatrend University, 2013.

2. Balkan Institute for Risk Assessment and Emergency Management. Institutional Capacity Assessment of Disaster Preparedness and Prevention Initiative. Belgrade, 2011.

3. Ekengren, M.; Matzén, N.; Svantesson, M. The New Security Role of the European Union: Transnational Crisis Management and the Protection of Union Citizens, Stockholm: Försvarshögskolan, 2006.

4. Frissel, E. H.; Oredsson, M. Building Crisis Management Capacity in the EU. Stockholm: FOI-Swedish Defence Research Agency, 2006.

5. Goldammer, J. G. Towards International Cooperation in Managing Forest Fire Disasters in the Mediterranean Region. In: Brauch, H.G., et al. (eds.). Security and Environment in the Mediterranean. Berlin-Heidelber: Springer, 2003.

6. Hamza, M. DPPI Capacity Development and Disaster Risk Reduction Training Courses - End of Project Report. 2012 [interactive]. [accessed on 23-11-2012]. $<$ http://www.dppi.info/system/files/DPPI\%20SEE\%20DRR_End\%20Project\%20 Report_2012.pdf>. 
7. Koellinger, P. The Relationship between Technology, Innovation, and Firm Performance - Empirical Evidence from E-business in Europe. Research Policy. 2008, Vol. 37.

8. Kešetović, Ž. The Disaster Preparedness and Prevention Initiative for South Eastern Europe [DPPI SEE]. ANVIL RO study [Draft], 2013.

9. Kešetović, Ž.; Milašinović, S.; Keković, Z.; Milošević, H. Crisis Management as Academic Discipline in Ex-Yugoslav Countries. In: Riešeniekrizovychsituacii $v$ špecifickomprostredi 3. čast, Žilinska Univerzita v Žiline-Fakulteta Špecialneho Inžinierstva/Ministerstvo gospodarstva SR-Odbor krizoveho manažmentu, 2011, p. 285-290.

10. Lopandić, D.; Kronja, J. Regionalne inicijative $i$ multilateralna saradnjana Balkanu [Regional Initiatives and Multilateral Cooperation in Balkans]. Belgrade: Evropskipokret u Srbiji, 2010.

11. Price, R. M.; Zacher, M. W. The UN and Global Security. New York: Palgrave Macmillan, 2004.

12. Stern, E. Crisis Decision Making - Cognitive Institutional Approach. Stockholm: Swedish National Defence College, 2003.

13. Special Co-ordinator of the Stability Pact for SEE Europe, Regional Report of the DPPI Operational Team. The Gorizia Document. May, 2001.

14. Vucetic, S. The Stability Pact for South Eastern Europe as a Security CommunityBuilding Institution. Southeast European Politics. 2001, 2(2): 109-134.

15. Williams, M. J. NATO, Security and Risk Management - From Kosovo to Kandahar. London and New York: Routledge, 2009.

Legal documents:

16. Disaster Preparedness and Prevention Initiative for South Eastern Europe. Memorandum of Understanding on the Institutional Framework on the Disaster Preparedness and Prevention Initiative for South Eastern Europe. 2007.

Internet sites:

17. <www.dppp.info>. [accessed on 23-11-2012].

Interviews [undertaken in 2012]:

18. DPPI SEE, Sarajevo.

19. Ministry of Security, Republic of Bosnia and Hercegovina, Sarajevo.

20. National Protection and Rescue Directorate, Republic of Croatia, Zagreb.

21. Ministry of Interior/Sector for Emergency Management, Republic of Serbia, Belgrade.

Želimir Kešetović, Višnja Samardžija

\section{Gyventojų saugumo regioninis bendradarbiavimas Pietryčių Europoje - atvejo analizè dèl parengties nelaimei ir prevencijos inicijavimo}

Anotacija

Straipsnyje siekiama išnagrinėti pasirengimo nelaimėms ir jų prevencijos iniciatyvos kokybės aspektus, kaip regioninė organizacija Pietryčių Europoje (DPPI SEE) siekia padidinti bendrą krizių valdymo pajègumą šiame krizių regione. 
Pasirengimo nelaimėms ir jų prevencijos iniciatyva Pietryčių Europoje yra vienintelè regioninè iniciatyva Pietryčių Europoje, kuri apima 11 valstybių partnerių (Albanija, Bosnija ir Hercegovina, Bulgarija, Kroatija, Makedonija, Juodkalnija, Moldova, Rumunija, Slovėnija, Serbija ir Turkija) ir dvi valstybes, turinčias stebėtojų statusą (Vengrija ir Graikija).

DPPI SEE buvo įsteigta 2000 metais lapkričio mènesị Stabilumo paktu Pietryčiu Europai, siekiant palengvinti bendradarbiavimą ir koordinavimą SEE šalyse, siekiant užkirsti kelią nelaimėms, pasirengti ir stiprinti pajègumus reaguoti ị stichines ir žmogaus sukeltas, t. y. technologines nelaimes. Po Stabilumo pakto pertvarkymo Pietryčių Europai 2008 metais DPPI SEE pateko po Regioninio bendradarbiavimo tarybos skèčiu.

Tais pačiais metais šalys partnerès pasirašė Supratimo memorandumą, kaip vienintelị teisinị pagrindą, reglamentuojantị tikslus, struktūrą ir sprendimų prièmimo procesą. DPPI SEE veikla yra pagrịsta gebejjimų, skirtų gerinti pasirengimą nelaimėms ir jų prevenciją per nelaimių valdymo mokymo ir lavinimo kursus, įskaitant seminarus, konferencijas ir t. t., ugdymu šalyse partnerèse. Svarbūs pasiekimai buvo padaryti per kelis regionus apimančių projektų igyvendinimą.

Vis dèlto, be svarbių DPPI SEE pasiektų darbo rezultatų, lieka ir kai kurių trūkumų. DPPI SEE dabar yra etape, kai nustatomi trūkumai numatant naują susitarimo memorandumą.

Straipsnyje kritiškai analizuojami kokybiniai DPPI SEE aspektai ir jos centrų veikimas siekiant nustatyti problemas ir didesnio šios regioninès organizacijos efektyvumo kliūtis, kurios gali padèti priimti sprendimus dèl būsimų norminès bazės pokyčių.

Želimir Kešetović - Belgrado universiteto Saugumo studijų fakulteto profesorius, politikos mokslų daktaras (Serbija).

E. paštas: zelimir.kesetovic@gmail.com

Želimir Kešetović, Doctor of Political Sciences, University of Belgrade in Serbia, Faculty of Security Studies, Full Professor.

E-mail: zelimir.kesetovic@gmail.com

Višnja Samardžija - Zagrebo pletros ir tarptautinių santykių instituto Ekonomikos fakulteto Europos integracijos katedros vadovas, ekonomikos mokslų daktaras (Kroatija).

E. paštas: visnja.samardzija@irmo.hr

Višnja Samardžija, Faculty of Economics, PhD; Institute for Development and International Relations, Zagreb, Croatia, Head of the Department for European Integration.

E-mail: visnja.samardzija@irmo.hr

Straipsnis įteiktas redakcijai 2014 m. vasario 19 d.; recenzuotas; parengtas spaudai $2014 \mathrm{~m}$. gegužès $30 \mathrm{~d}$. 